\section{6. 千葉大学病院年術部内の淯浄度について}

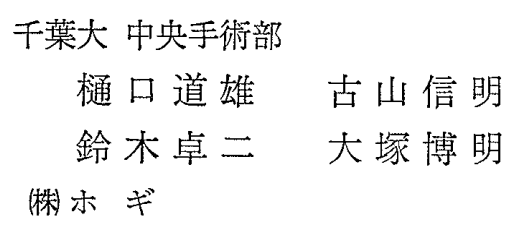

竹村行夫森山正人

当院のバイオクリーン手術室の清浄度については以 前報告したが，今回はそれ以外の手術部内各場所の清 浄度を, 空中浮遊塺埃数, 空中浮遊細菌数预よび床付 着細菌数を測定して検討した。

空中浮遊塵埃数は光散乱式粒子計数器 (Rion $\mathrm{KC}$ -

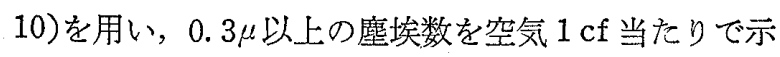
した. 空中浮遊細菌数怯, Air Sampler(Biotest RCS) を用い，空気 $1 \mathrm{cf}$ 当たりのコロニー数で示した．床面 付着細菌数は，スタンプメデイア（栄研 BH 1) を使 用し, 床面 $10 \mathrm{~cm}^{2}$ 当たりのコロニー数で示した.

空中浮遊塺埃数を $(0.3,0.5,1.0,2.0,5.0) \mu$ V 分けてみると，手術部外一般通路（非清潔区域）では $(21765 ， 1440 ， 145 ， 19 ， 1) \times 10^{2}$ を数えたのに対し， 手術室内で空調使用時には $(20,4,2,1.0) \times 10^{2}$, 手術室内空調使用時, 数人移動の状態では $(142 ， 25$,

$9 ， 2 ， 0) \times 10^{2}$ であった。乙かし空調を用いない場合 には，手術室内でも $(1424,226,106,35,1) \times 10^{2}$ と著明な増加が認められた。

手術部内（清潔区域）にあって, 手術室以外の, 例 えば器材室や暗室などでは, 空調時 $(283,66,29$, $9,2) \times 10^{2}$, 空調時数人移動状態で（392，87，38, 10，1）×102であったが，非空調時には（1549，238， $106 ， 30 ， 1) \times 10^{2}$ 之著しく増加した。

手術部内廊下（清潔区域）では，空調時（195，33， $9,2,0) \times 10^{2}$, 空調時数人移動の場合 $(528,62,16$, $3,0) \times 10^{2}$, 非空調時 $(1442,230,108,38,2) \times 10^{2}$ であった。

浮遊細菌数を一般菌でみると，48時間培養の結果， 手術室内では空調時 $0 \sim 8$ 個で平均 4 個, 手術部内廊 下で $1 \sim 32$ 個 (平均 15 個), 非空調時で注平均約 40 個 検出された。

床上細菌数は当然のことながら患者搬送口付近でそ の数が多く, 48 時間培養で $10^{3} \sim 10^{5}$ の単位で検出され た。しかし手術室内では，10 20個のコロニー数であ った.

以上当院の手術部内の清浄度について報告したが, いまだ決して満足すべきものではない. 今後とも厳重 な污染対策などをこうじる一方，手術室利用者の積極
的な協力を希望していきたいと考えている。

\section{7. 箕面市立病院における初発基礎殺菌処理亡 開院後 3 力月間の清潔区域内における微生 物污染度の推移について}

\author{
箕面市立病院 外科 \\ 栗山 洋梅下浩司 \\ 亀山雅男明石英男 \\ 水本正剛 青木行俊 \\ 筫面市立病院 中央手術部 \\ 井手尾純一 \\ 環境衛生薬品森 \\ 馬 頭 美 恵
}

近年病院内の感染は重要な問題となってきている. ところが原因ともいえる病院内各区域の微生物污染の 程度やその変化については一部の Bioclean roomを 除き詳らかな調查はなされていない，今回，箕面市立 病院開院（昭和56年 7 月）に当たり, 初発基礎殺菌処 理を行い,さらに清潔区においては開院後 3 力月閒, 微生物污染度の推移を検討したので報告する。

[方法] 対象は清潔区 $556 \mathrm{~m}^{2}$, 淮清潔区 $515 \mathrm{~m}^{2}$, 一 般区 $6755 \mathrm{~m}^{2}$ の計 $7826 \mathrm{~m}^{2}$ である. 使用薬肪, 濃度, 噴霧回数として,クロールヘキシジングルコネート $0.2 \%$ 液, $25 \mathrm{ml} / \mathrm{m}^{2}$ を 3 回, 2 回, およびグルタール アルデヒド $0.1 \%$ 液 $25 \mathrm{ml} / \mathrm{m}^{2} 3$ 回, 1 回である. 噴 霧はハンドスプレー,電動スプレー,マイクロジェンに よった，殺菌処理効果はスタンプ法による物体表面付 着菌量を指標とした，殺菌処理前は市販のスタンプア ガー(栄研 1 号), 処理後はスタンプメディア BH I を用い, $10 \mathrm{~cm}^{2}$ 当たりに形成される微生物集落を $31^{\circ} \mathrm{C}$ 48時間培盖後計数した。

[成績] (1)初発殺菌処理: 各区域の処理前・処理後 の菌数平均值を示す. 3 回噴霧の清潔区 (手術空 3.04 $\rightarrow 0.14$, 中央滅菌材料室 $6.64 \rightarrow 0.08$, 輸液調製室 $7.96 \rightarrow 0$, 調乳室 $31.81 \rightarrow 0.03), 2$ 回噴霧の準清潔区 （手術準備室 $2.45 \rightarrow 0.24$, 洗浄室 $\cdots$ 略）ともに平均 值 1.0 以下, 最大值 5 以下を示し良好な处理効果が得 られた。. 1 回噴霧の一般区もかなりの効果が認められ た.

(2) 3 カ月後の推移: 手術室は平均 6.94 であるが, 仮に廊下の污染のひどい部位を除くと平均 2.88 とな る。中央滅菌材料室と輸液調製室は日常管理が良好な ことを示した。調乳室は 1 カ月ですでに平均 8 を越え 細か心配慮の必要なことが認められる. 以上の検討結 
果加 $4 \sim 6$ 力月に 1 回, 今回と同程度の大掃除的殺 菌処理が必要ではないかと考えられる。 今後さらに検 討を加えたい，

\section{8. 病院ベッド用マットレスの細菌学的活染 に関する研究}

\author{
名古屋大 高気圧治療部 \\ 高橋英世 小林繁夫 \\ 榊 原欣作 \\ 名古屋大 看護部 \\ 加藤 順子棚橋阿さ子 \\ 㮫キャップロール \\ 田中延和、岩上正雄 \\ 富田三郎浜須光由
}

従来，医療関連機器の1つとして認識されることの 少なかった病院ベッド用マットレスに関し，筆者らは 使用者としての患者および医療従事者の双方の立場か ら医学的な検討を加え，理想的な病院ベッド用マット レスの開発を企図してきた。既に，本学会第55回大会 において，独自の観点から開発した特殊な三層構造を 有する病院ベッド用マットレスとその試用結果を報告 し，第56回大会に扔いては，さらに改良を加えた新し い三層構造マットレス，および長期間使用した三層構 造マットレスの材質疲労に関する研究結果とを報告し た。 今回は残された重要な課題の 1 つである病院ベッ ド用マットレスの細菌学的污染に関し, 調查, 研究を 行っているので，その結果を報告する.

病院ベッド用マットレスの細菌学的污染に関するも っとも有効な検查法については，現在なお模菜中であ るが，今回の研究に拉いて採用した方法はスタンプ法 である。一般に, ある環境の細菌学的衛生管理には, 被検查物表面のふきとり法が採用されるが，この方法 は各種の器具と技術を必要とし, 検查者の習熟度によ る個人差が検查成績に反映されるなどの欠点を有す る、そこで今回は，特殊な手技を必要とせず，簡便に 細菌污染の大要を知ることのできる指標として, 標準 寒天培地を用いた市販のスタンプ 法キットを導入し た. 筆者らの開発した三層構造マットレスは，その独 自の構造と材質加通気性に優れ, 長期間, 清潔な環 境を保持できることが特徴のつであるが，本研究におる いては，三層構造マットレス各層の通気性の差異によ る污染度の比較, および使用期間, 使用条件などが污 染度に及ぼす影響などを検討する，さらに細菌集落数 による污染度の評価に加え, 菌種の同定をも行うこと
により，病院ベッド用マットレスの細菌学的污染の特 異性と，その対策としての消毒・滅菌法に関しても論 及する予定である。

\section{9. 修理・保守管理に出される医科器械類の消 法の祫討}

都立アイソトープ総合研究所

細淵和成 関口正之

田部井雅枝 佐 藤 健二

医科器械類の安全性の確保の立場から, 病医院, 大 学・研究機関で再タ使用された医科器械類は, 製造業 者のもとに送り，修理・保守管理を行うことがある。 この場合, これら医科器械類は患者等に使用されたた め, 病原菌で污染されている場合が考光られるので, 搬出前に何らかの消毒処理が行われる.

そこで修理・保守管理に出される医科器械類の簡易 な消毒法を求めるため, 医科器诫類の污染菌等に対す る消毒薬の抵抗性について検討したので報告する.

〔方法】污染菌採集方法：スメア法㧠よび Direct surface agar plate 法により行い，医科器械類に付着 している細菌を採集した。

污染菌および指標菌に対する消毒薬の抵抗性測定： 常法の MIC (最小発育阻止濃度) 法および石炭酸倸数 法により消毒薬の抵抗性を測定した。な扔消毒薬とし ては，クロルヘキシジン，塩化ベンザルコニウム，フ エノール等を用いた.

[結果]修理される医科器械類として, 吸引器, メ ス，八サミ，鉗子等があり，特に污染の著しいものと して, 吸引器があげられた。 そこで吸引器より污染菌 を採集し，同定を行ったところ緑膿菌等が検出された 例も認められた。

次に污染菌および指標菌に対する消毒薬の MICを 求めたところ，クロルヘキシジンでは $0.04 \%$, 塩化べ ンザルコニウムでは $0.1 \%$ ，フェノールでは $0.5 \%$ であ った。 また，石炭酸俰数法の変法により各菌が 4 分で 死減する消需薬の濃度は，クロルヘキシジンでは0. 05

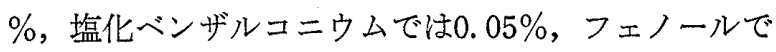

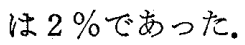

